Annals of Plant and Soil Research 22(4): 437-441 (2020)

https://doi.org/10.47815/apsr.2020.10018

\title{
Isolation, identification and characterization of phosphate solubilizing bacteria in soils of coal mines landfills of Chhattisgarh
}

\author{
NELSON XESS ${ }^{*}$ AND SHWETA SAO
}

Microbiology Department, Dr. C.V. Raman University, Kota, Bilaspur, Chhattisgarh, India

Received: July, 2020; Revised accepted: August, 2020

\begin{abstract}
Phosphate solubilizing bacteria have the ability to solubilize the insoluble phosphates and to improve the quality of soil health and fertility. Efficacy of phosphate solubilizing microorganisms has been identified on the basis of kinetics and phosphorus accumulation. In this study, twenty eight soil samples were collected from different coal mines landfills of Chhattisgarh and occurrence of phosphate solubilizing bacteria (PSB) was isolated, purified and identified. In addition, the phosphate solubilizing capacity of bacteria based on the formation of visible or halo zone on Pikovskaya agar plates (PVK) and broth having tricalcium phosphate (TCP) and rock phosphate (RP) as a phosphate source was estimated at Dr. C.V. Raman University, Kota, Bilaspur (Chhattisgarh). The result revealed dominance of Pseudomonas syringae as major phosphate solubilizers, along with Bacillus subtillis followed by Pantoea dispersa, Bacillus circulans. Use of these PSB as bioinoculants increased the available $P$ in soil to the extent of 194 and $246 \mu \mathrm{g} / \mathrm{ml}$ of $P$. the soluble $P$ in case of rock phosphate was less than tricalcium phosphate. The maximum solubilization was observed after 15 days follow by a decrease in amount of soluble $P$.
\end{abstract}

Keywords: Phosphate solubilizing bacteria, rock phosphate, tricalcium phosphate, coal minerals.

\section{INTRODUCTION}

Phosphorus is the major essential macronutrient of plants and its deficiency is a severe constraint to crop production. Phosphorus is known to involve many functions in plant growth and metabolism. Though soils may have a large reservoir of total phosphorus the amount available to plants is usually but very small proportion of the total phosphorus (Majumdar and Chakraboty 2015). Phosphorus is abundant both in organic and inorganic forms. There are various types of rhizobacteria that can solubilize this fixed form of $P$ and make it available to plants. Such organisms are called Phosphate Solubilizing bacteria. Several phosphate solubilizing bacteria are now known to convert the insoluble form of phosphorus to soluble form through the secretion of chelating organic acid or protons and thus lowering the $\mathrm{pH}$ (Richardson et al. 2009). PSBs, particularly those belonging to the genera Pseudomonas and Bacillus possess the ability to convert the insoluble phosphate into a soluble form (Fankem et al.2006). Plant takes phosphate in the form of soluble orthophosphate ions $\left(\mathrm{H}_{2} \mathrm{PO}_{4}{ }^{-}\right.$and $\mathrm{HPO}_{4}{ }^{2-}$ ). Phosphate rocks should provide a cheap source of phosphorus fertilizer for agricultural use. Inoculation of phosphate solubilizing bacteria with rock phosphate may be considered a better means to overcome the low solubility problems of rock phosphate (Jaleel Basha et al. 2018). The unmanaged excess of phosphate application is known to cause environmental problems. The use of such a natural resource constitutes an economic, environmentally friendly, and efficient way of fertilizing crops. In the present study, different strains of PSB using biochemical tests were isolated and identified and investigate highly efficient solubilizers of TCP and RP.

\section{MATERIALS AND METHODS}

Total 28 soil samples were randomly collected from different coal mines landfills of Korea, Korba and Surajpur districts, S.E.C.L. (South Eastern Coalfields Limited) Chhattisgarh, India and stored at $4^{\circ} \mathrm{C}$ in the laboratory, Department of Life science, University of Dr. C.V Raman University, Kota, Bilaspur for further study. These soil samples were serially diluted using sterile water blanks and plated on the Pikovskaya Agar medium (Marra et al.2012). The plates were incubated at $37^{\circ} \mathrm{C}$ for $2-4$ days. After incubation, the phosphate solubilizing microorganisms were selected based on the zone of clearing around the colonies. The isolated phosphate solubilizing bacteria were purified by repeated culturing and maintained on 
Nutrient Agar slants at $4^{\circ} \mathrm{C}$. The most bacterial isolates were identified using standard biochemical tests (Poonguzhali et al. 2008).

Screening of PSB: Pure culture of phosphate solubilizing bacteria was spot inoculated on Pikovskaya agar plates and incubated at $37^{\circ} \mathrm{C}$. For this Pikovskaya agar plates were formally divided into two parts. 10 1 l suspension of two days grown culture of bacteria isolates was used to inoculate the center of each half part of the petriplate. The halo zone of phosphate solubilization around growth was recorded (in $\mathrm{mm}$ ) after every 24 hours of incubation. The colonies forming more than $5.0 \mathrm{~mm}$ zone of solubilization were selected as efficient strains (Hamadali et al. 2008).

Estimation of phosphate solubilization of tricalcium phosphate: Pikovskaya broth (100 $\mathrm{ml}$ ) was dispensed in $250 \mathrm{ml}$ conical flasks and TCP (109 mg equivalent $50 \mathrm{mg} \mathrm{P}_{2} \mathrm{O}_{5}$ ) was added as a phosphorus source. The flasks were inoculated with bacterial isolates and allowed to grow for different periods of time at $37^{\circ} \mathrm{C}$. The soluble phosphorus was determined by the method given by Chen et al. (2006). The pH of culture filtrates was also measured.

\section{RESULTS AND DISCUSSION}

\section{Isolation and Enumeration of PSB}

The Pikovskaya agar plate was inoculated with the suspensions such as $10^{-2}$ and $10^{-4}$, showed more colonies, and no bacterial colonies showed in $10^{-5}$ dilution (Table 1).Dunfield and Germida, (2001) also supported that the initial isolation of phosphate solubilizers is usually made by using

Table 1: Total rhizobacterial and phosphate solubilizing bacteria present in different coal mines landfills area

\begin{tabular}{|c|c|c|c|c|c|c|c|c|c|c|c|}
\hline \multirow{3}{*}{ District } & \multirow{3}{*}{ Coalfields } & \multicolumn{5}{|c|}{ Rhizobacterial } & \multirow{2}{*}{\multicolumn{5}{|c|}{$\begin{array}{c}\text { Phosphate solubilizingbacteria } \\
\text { Dilution }\end{array}$}} \\
\hline & & & & Dilu & & & & & & & \\
\hline & & $10^{-2}$ & $10^{-3}$ & $10^{-4}$ & $10^{-5}$ & $\begin{array}{c}\text { Cfu/g of } \\
\text { soil }\end{array}$ & $10^{-2}$ & $10^{-3}$ & $10^{-4}$ & $10^{-5}$ & $\begin{array}{c}\text { Cfu/g of } \\
\text { soil }\end{array}$ \\
\hline Korea, & Chirmiri Area & $>300$ & 192 & 87 & 7 & $87 \times 10^{5}$ & 49 & 20 & 9 & 0 & $9 \times 10^{5}$ \\
\hline Chhattisgarh & Baikunthpur Area & $>300$ & 178 & 81 & 6 & $81 \times 10^{b}$ & 43 & 22 & 9 & 0 & $9 \times 10^{5}$ \\
\hline Korho & Kusmunda & 291 & 172 & 48 & 3 & $48 \times 10^{5}$ & 21 & 9 & 4 & 0 & $4 \times 10^{5}$ \\
\hline Chhattis & Dipka & $>300$ & 184 & 42 & 5 & $42 \times 10^{5}$ & 47 & 22 & 7 & 0 & $7 \times 10^{5}$ \\
\hline Unnattis & Gevra & $>300$ & 127 & 41 & 3 & $41 \times 10^{5}$ & 38 & 16 & 5 & 0 & $5 \times 10^{5}$ \\
\hline Surajp & Bhatc & 286 & 124 & 55 & 4 & $55 \times 10^{5}$ & 24 & 13 & 4 & 0 & $4 \times 10^{5}$ \\
\hline Chhattiss & Bishrampur & $>300$ & 203 & 71 & 5 & $71 \times 10^{5}$ & 39 & 14 & 5 & 0 & $5 \times 10^{5}$ \\
\hline
\end{tabular}

a medium suspended with insoluble phosphates such as tricalcium phosphates. These findings were also supported by Keneni et al. (2010). From these soil samples, total 425 bacterial strains were isolated on Pikovskaya agar plates by serial dilution method at $10^{-4}$ dilution. Out of these 425 bacterial isolates, only 43 bacterial isolates were observed to be formed a halo zone surrounding the colonies that were the $10 \%$ of total bacterial population isolated (Table 2). Mohan and Menon (2015) reported the same results in their study.

Table 2: Population density andqualitative screeningof phosphate solubilizing bacteria in different coal mines landfills area

\begin{tabular}{|c|c|c|c|c|c|}
\hline District & Coalfields & $\begin{array}{c}\text { Population } \\
\text { density of } \\
\text { Rhizobacteria } \\
10 \% \text { of soil }\end{array}$ & $\begin{array}{l}\text { Population } \\
\text { of PSB } \\
10^{5} / \mathrm{g} \text { of soil }\end{array}$ & $\begin{array}{c}\text { No. of less efficient } \\
\text { bacteria ( }>5 \mathrm{~mm} \\
\text { zone of } \\
\text { solubilization) }\end{array}$ & $\begin{array}{c}\text { No. of efficient } \\
\text { bacteria (<5mm zone } \\
\text { of solubilization) }\end{array}$ \\
\hline Korea, & Chirmiri & 87 & 9 & 7 & 2 \\
\hline Chhattisgarh & Baikunthpur & 81 & 9 & 8 & 1 \\
\hline Korba, & Kusmunda & 48 & 4 & 4 & 0 \\
\hline Chhattisgarh & Dipka & 42 & 7 & 4 & 3 \\
\hline & Gevra & 41 & 5 & 3 & 2 \\
\hline Surajpur, & Bhatgaon & 55 & 4 & 3 & 1 \\
\hline Chhattisgarh & Bishrampur & 71 & 5 & 3 & 2 \\
\hline Total & & 425 & 43 & 32 & 11 \\
\hline
\end{tabular}




\section{Qualitative screening of PSB}

Qualitative screening of phosphate solubilizing bacterial isolates revealed variations in phosphate solubilization efficiency of selected isolates. Data showed that the section of efficient phosphate solubilizing bacterial isolated on qualitative basis. The data (table 3 ) indicated the value of the diameter of the colony $(\mathrm{C})$, diameter of halo zone $(\mathrm{H})$, diameter of colony+ halo zone $(\mathrm{Z})$ and the ratio $\mathrm{Z} / \mathrm{C}$ of different isolates obtained on PKV agar plates showed more than $5 \mathrm{~mm}$ zone of phosphate solubilization. The use of the ratio $\mathrm{Z} / \mathrm{C}$ helps to evaluate the activity of a given microorganism. The phosphate solubilization activity of these selected isolates on PVK agar plates ranged from 1.33 to 2.55 (Table 3).

Table 3: Phosphate solubilization activity of selected bacterial isolates

\begin{tabular}{|c|c|c|c|c|}
\hline Isolates & $\begin{array}{c}\text { Diameter of } \\
\text { colony (C) }\end{array}$ & $\begin{array}{c}\text { Diameter of halo zone } \\
\mathbf{( H )}\end{array}$ & $\begin{array}{c}\text { Diameter of } \\
\text { (colony+ halo zone) } \\
(\mathbf{Z})\end{array}$ & $\begin{array}{c}\text { Solubilization } \\
\text { activity (Z/C) }\end{array}$ \\
\hline PSB 1 & 11 & 5 & 16 & 1.45 \\
PSB 2 & 9 & 11 & 20 & 2.22 \\
PSB 3 & 14 & 6 & 20 & 1.42 \\
PSB 4 & 12 & 4 & 16 & 1.33 \\
PSB 5 & 9 & 12 & 21 & 2.33 \\
PSB 6 & 14 & 5 & 19 & 1.35 \\
PSB 7 & 9 & 6 & 15 & 1.66 \\
PSB 8 & 4 & 5 & 9 & 2.25 \\
PSB 9 & 9 & 14 & 23 & 2.55 \\
PSB 10 & 7 & 5 & 12 & 1.71 \\
PSB 11 & 12 & 5 & 17 & 1.41 \\
\hline
\end{tabular}

Solubilization of tri-calcium phosphate and rock phosphate

The quantitative solubilization and screening were done in Pikovskaya broth having tricalcium phosphate (TCP) and rock phosphate (RP) as a phosphate source. The quantitative tests to assay the relative efficiency of the phosphate solubilizing microorganisms are based on the lowering of $\mathrm{pH}$, owing to the production of organic acids into the surrounding medium. Out of 11 bacteria isolates, only 4 isolates were found to be highly efficient solubilizers of TCP which showed maximum solubilization in fifteen days. These four isolates were PSB 2, PSB 5, PSB 8 and PSB 9. These isolates showed maximum solubilization between 194 and $246 \mu \mathrm{g} / \mathrm{ml}$ of $\mathrm{P}$ and PSB 9 showed maximum solubilization at $15^{\text {th }}$ day was $246 \mu \mathrm{g} / \mathrm{ml}$ of $\mathrm{P}$ (Table 4).

Table 4: Soluble phosphate and $\mathrm{pH}$ reduction of the Pikovskaya media (TCP equivalent to $50 \mathrm{mg}$ $\mathrm{P}_{2} \mathrm{O}_{5}$ inoculated with 11 bacterial isolates after different time intervals

\begin{tabular}{c|cc|c|c|c|c|c|c|}
\hline $\begin{array}{c}\text { Bacterial } \\
\text { Isolates }\end{array}$ & $\begin{array}{c}\text { Soluble P } \\
(\mu \mathrm{g} / \mathrm{ml}) \text { After } \\
5 \text { Days }\end{array}$ & $\begin{array}{c}\text { After 5 } \\
\text { Days } \\
\text { pH }\end{array}$ & $\begin{array}{c}\text { Soluble P } \\
(\mu \mathrm{g} / \mathrm{ml}) \\
\text { After } 10 \\
\text { days }\end{array}$ & $\begin{array}{c}\text { After 10 } \\
\text { days } \\
\text { pH }\end{array}$ & $\begin{array}{c}\text { Soluble P } \\
(\mu \mathrm{g} / \mathrm{ml}) \\
\text { After } 15 \\
\text { days }\end{array}$ & $\begin{array}{c}\text { After 15 } \\
\text { days } \\
\mathrm{pH}\end{array}$ & $\begin{array}{c}\text { Soluble P } \\
(\mu \mathrm{g} / \mathrm{ml}) \\
\text { After 20 } \\
\text { days }\end{array}$ & $\begin{array}{c}\text { After 20 } \\
\text { days } \\
\mathrm{pH}\end{array}$ \\
\hline PSB1 & $32.32 \pm 3$ & $5.45 \pm 0.4$ & $39.47 \pm 0.4$ & $5.21 \pm 0.5$ & $31.21 \pm 0.3$ & $5.17 \pm 0.3$ & $31.76 \pm 0.5$ & $5.15 \pm 0.2$ \\
PSB2 & $64.75 \pm 3$ & $5.10 \pm 0.3$ & $184.56 \pm 2$ & $4.55 \pm 0.7$ & $194.21 \pm 4$ & $4.32 \pm 0.3$ & $181.51 \pm 5$ & $4.22 \pm 0.5$ \\
PSB3 & $39.05 \pm 2$ & $5.12 \pm 0.1$ & $98.00 \pm 4$ & $4.86 \pm 0.4$ & $81.22 \pm 5$ & $4.78 \pm 0.3$ & $87.36 \pm 5$ & $4.67 \pm 0.4$ \\
PSB4 & $32.38 \pm 4$ & $5.82 \pm 0.4$ & $62.12 \pm 5$ & $5.09 \pm 0.5$ & $76.29 \pm 5$ & $4.78 \pm 0.2$ & $72.81 \pm 3$ & $4.48 \pm 0.3$ \\
PSB5 & $58.10 \pm 3$ & $6.50 \pm 0.4$ & $180.18 \pm 5$ & $6.21 \pm 0.4$ & $235.00 \pm 3$ & $4.48 \pm 0.2$ & $229.22 \pm 5$ & $4.43 \pm 0.2$ \\
PSB6 & $45.76 \pm 2$ & $6.64 \pm 0.4$ & $70.12 \pm 3$ & $5.75 \pm 0.3$ & $71.75 \pm 4$ & $5.46 \pm 0.4$ & $65.43 \pm 5$ & $5.42 \pm 0.4$ \\
PSB7 & $38.12 \pm 4$ & $4.46 \pm 0.2$ & $80.21 \pm 2$ & $4.33 \pm 0.4$ & $97.71 \pm 5$ & $4.20 \pm 0.3$ & $102.08 \pm 3$ & $4.13 \pm 0.3$ \\
PSB8 & $79.38 \pm 5$ & $5.23 \pm 0.6$ & $181.40 \pm 5$ & $4.22 \pm 0.4$ & $203.12 \pm 3$ & $4.33 \pm 0.45$ & $192.12 \pm 5$ & $4.15 \pm 0.4$ \\
PSB9 & $52.38 \pm 0$ & $6.14 \pm 0.2$ & $204.22 \pm 3$ & $4.82 \pm 0.2$ & $246.00 \pm 2$ & $4.10 \pm 0.4$ & $237.10 \pm 4$ & $4.24 \pm 0.2$ \\
PSB10 & $52.48 \pm 4$ & $5.32 \pm 0.4$ & $60.00 \pm 2$ & $4.78 \pm 0.2$ & $91.74 \pm 4$ & $4.12 \pm 0.4$ & $106.21 \pm 4$ & $4.04 \pm 0.2$ \\
PSB11 & $28.54 \pm 4$ & $6.75 \pm 0.4$ & $54.32 \pm 2$ & $6.64 \pm 0.4$ & $98.72 \pm 2$ & $6.54 \pm 0.3$ & $91.45 \pm 3$ & $6.47 \pm 0.2$ \\
\hline
\end{tabular}


Highly efficient solubilizers of TCP which showed maximum solubilization of four isolates PSB 2, PSB 5, PSB 8 and PSB 9 were tested for bacterial solubilization of the rock phosphate (149.6 mg equivalent $50 \mathrm{mg} \mathrm{P}_{2} \mathrm{O}_{5}$ in $100 \mathrm{ml}$ PKV broth). The soluble $P$ in case of $R P$ was less than TCP in the isolates. The maximum solubilization was observed after fifteen days and after that the soluble $P$ decreased. These four isolates showed significantly highly efficient solubilization of rock phosphate (20 to $34 \mu \mathrm{g} / \mathrm{ml}$ of $\mathrm{P}$ ) and $\mathrm{pH}$ range was 4.1 to 4.4 (Table 5).

Table 5: Soluble phosphate and $\mathrm{pH}$ reduction of the Pikovskaya media (rock phosphate equivalent to $50 \mathrm{mg} \mathrm{P} \mathrm{P}_{5}$ ) inoculated with 4 bacterial isolates after different time intervals

\begin{tabular}{c|c|c|c|c|c|c|c|c|}
\hline $\begin{array}{c}\text { Bacterial } \\
\text { Isolates }\end{array}$ & $\begin{array}{c}\text { Soluble } \mathrm{P} \\
(\mu \mathrm{g} / \mathrm{ml}) \\
\text { After } 5 \text { days }\end{array}$ & $\begin{array}{c}\text { After } 5 \\
\text { days } \\
\mathrm{pH}\end{array}$ & $\begin{array}{c}\text { Soluble } \mathrm{P} \\
(\mu \mathrm{g} / \mathrm{ml}) \\
\text { After } 10 \text { days }\end{array}$ & $\begin{array}{c}\text { After } 10 \\
\text { days } \\
\mathrm{pH}\end{array}$ & $\begin{array}{c}\text { Soluble } \mathrm{P} \\
(\mu \mathrm{g} / \mathrm{ml}) \\
\text { After } 15 \text { days }\end{array}$ & $\begin{array}{c}\text { After } 15 \\
\text { days } \\
\mathrm{pH}\end{array}$ & $\begin{array}{c}\text { Soluble } \mathrm{P} \\
(\mu \mathrm{g} / \mathrm{ml}) \\
\text { After } 20 \text { days }\end{array}$ & $\begin{array}{c}\text { After } 20 \\
\text { days } \\
\mathrm{pH}\end{array}$ \\
\hline PSB2 & $7.89 \pm 2$ & $6.14 \pm 0.5$ & $14.46 \pm 3$ & $5.45 \pm 0.2$ & $21.05 \pm 2$ & $4.10 \pm 0.4$ & $18.18 \pm 4$ & $4.24 \pm 0.2$ \\
PSB5 & $12.18 \pm 2$ & $5.42 \pm 0.4$ & $19.46 \pm 4$ & $5.12 \pm 0.4$ & $30.85 \pm 3$ & $4.48 \pm 0.4$ & $29.02 \pm 2$ & $4.18 \pm 0.2$ \\
PSB8 & $8.56 \pm 3$ & $6.10 \pm 0.5$ & $12.21 \pm 5$ & $5.22 \pm 0.4$ & $20.12 \pm 5$ & $4.11 \pm 0.2$ & $19.18 \pm 5$ & $4.05 \pm 0.5$ \\
PSB9 & $14.26 \pm 3$ & $5.85 \pm 0.3$ & $21.72 \pm 4$ & $5.23 \pm 0.6$ & $34.44 \pm 4$ & $4.44 \pm 0.4$ & $32.19 \pm 2$ & $4.22 \pm 0.5$ \\
\hline
\end{tabular}

Based on the biochemical tests, the PSB isolates, named PSB 2, PSB 5, PSB 8 and PSB 9 were identified as Bacillus subtillis, Bacillus circulans, Pantoea dispersa and Pseudomonas syringae (Table 6). The PSB strains were identified up to species level. Kumar et al. (2012) studied the bacterial cultures morphological, cultural and physiological, and biochemical characteristics and identified the organism Bacillus sp., Richardson (2001) found that the predominant soil bacteria involved in phosphate solubilization include Bacillus and Pseudomonas.

Table 6: Morphological, physiological, and biochemical characteristics of phosphate solubilizing bacteria strains

\begin{tabular}{c|c|c|c|c|}
\hline \multirow{2}{*}{ Characteristics } & \multicolumn{4}{|c|}{ PSB strains Code No. } \\
\cline { 2 - 5 } & PSB2 & PSB5 & PSB8 & $P S B 9$ \\
\hline Gram staining & Gram positive & Gram positive & Gram negative & Gram negative \\
Shape of cell & Rod & Short Rod & Rod & Short Rod \\
Spore & Sporulating & Sporulating & Non-Sporulating & Non-Sporulating \\
Pigments & No pigment & No pigment & Yellow & Creamy white \\
Motility & Motile & Motile & Motile & Motile \\
Catalase & + & + & + & + \\
Oxidase & - & - & - & + \\
Methyl red & - & - & + & - \\
Voges Proskauer & + & - & + & - \\
Indole & - & - & - & - \\
$\mathrm{H}_{2}$ S production & + & - & + & + \\
Citrate Utilization & + & - & - & - \\
Starch hydrolysis & + & + & - & + \\
Casein hydrolysis & + & + & + & + \\
Gelatin hydrolysis & + & + & + & + \\
Oxidative fermentation & - & - & - & - \\
Anaerobic growth & - & - & - & + \\
Urease & - & - & + \\
\hline
\end{tabular}

Result showed Pseudomonas syringae has greater phosphatesolubilization efficiency along with Bacillus subtillis followed by Pantoea dispersa and Bacillus circulans. 


\section{REFERENCES}

Chen, Y.P, Rekha, P.D, Arun, A.B, Shen, F.T, Lai, W.A, and Young, C.C. (2006) Phosphate solubilizing bacteria from subtropical soil and their tricalcium phosphate solubilizing abilities. Applied Soil Ecology 34(1):33-41.

Dunfield, K.E, and Germida, J.J. (2001) Diversity of bacterial communities in the rhizosphere and root interior of fieldgrown genetically modified Brassica napus. FEMS Microbiology Ecology 38(1): $1-9$.

Fankem, H., D. Nwaga, A. Deubel, L. Dieng, W. Merbach \& F. X. Etoa. (2006) Occurrence and functioning of phosphate solubilizing microorganisms from oil palm tree (Elaeis guineensis) rhizosphere in Cameroon. African Journal of Biotechnology 5(24): 2450-2460.

Hamadali, H, Hafidi, M, Virolle, M.J, and Ouhdouch, Y (2008) Rock phosphate solubilizing actinomycetes: screening for plant growth promoting activities. World Journal of Microbiology and Biotechnology 24(11): 2565-2575.

Jaleel Basha,I. Singh, A.K., Engrala Ao, and Gupta R.C. (2018) Evaluation of Udaipur rock phosphate as phosphorus fertilizer in soyabean (Glycine max L. Merrill) grown on acid upland soils of Nagaland. Journal of the Indian Society of Soil Science 66(1): 83-88

Keneni, A., Assefa, F., Prabu, P.C. (2010) Isolation of phosphate solubilizing bacteria from the rhizosphere of faba bean of Ethiopia and their abilities on solubilizing insoluble phosphates.Journal of Agricultural Science and Technology 12: 79-89.

Kumar, P, Dubey R.C, and Maheshwari, D.K. (2012) Bacillus strains isolated from rhizosphere showed plant growth promoting and antagonistic activity against phytopathogens. Microbiological Research 167(8): 493-499.

Majumdar, S., and Chakraboty, U. (2015) Phosphate solubilizing rhizospheric Pantoea agglomerans Acti-3 promotes growth in jute plants. World Journal of Agricultural Sciences 11(6): 401-410.

Marra, L.M, Soares, CRFSS, de Oliveira, S.M, Ferreira, P.A.A.A, Soares, B.L, Carvalho, R.F, Lima, J.M, and Moreira, F.M. (2012) Biological nitrogen fixation and phosphate solubilization by bacteria isolated from tropical soils. Plant and Soil 357(1): 289-307.

Mohan, V., Menon, S. (2015) Diversity Status of Beneficial Microflora in Saline Soils of Tamil Nadu and Pudhucherry in Southern India. Journal of Academia and Industrial Research 3(8):384-392.

Poonguzhali, S., Madhaiyan, M., Sa T, (2008) Isolation and identification of phosphate solubilizing bacteria from chinese cabbage and their effect on growth and phosphorus utilization of plants. Journal of Microbiology and Biotechnology 18(4):773-777.

Richardson, A. E. (2001) Prospects for using soil microorganisms to improve the acquisition of phosphorus by plants. Australian Journal of Plant Physiology 28(9): 897-906.

Richardson, A.E., Barea, J.M., McNeill, A.M. and Prigent-Combaret, C. (2009) Acquisition of phosphorus and nitrogen in the rhizosphere and plant growth promotion by microorganisms. Plant and Soil 321(12): 305-339. 